Swarthmore College

Works

Spring 1997

\title{
A Garment Dipped In Blood: Ololon And Problems Of Gender In Blake's "Milton"
}

Betsy Bolton
Swarthmore College, bbolton1@swarthmore.edu

Follow this and additional works at: https://works.swarthmore.edu/fac-english-lit

Part of the English Language and Literature Commons

Let us know how access to these works benefits you

\section{Recommended Citation}

Betsy Bolton. (1997). "A Garment Dipped In Blood: Ololon And Problems Of Gender In Blake's "Milton"'". Studies In Romanticism. Volume 36, Issue 1. 61-101. DOI: 10.2307/25601212

https://works.swarthmore.edu/fac-english-lit/46

This work is brought to you for free by Swarthmore College Libraries' Works. It has been accepted for inclusion in English Literature Faculty Works by an authorized administrator of Works. For more information, please contact myworks@swarthmore.edu. 


\section{"A Garment dipped in blood": Ololon and Problems of Gender in Blake's Milton}

Would to God that all the Lords people were Prophets.

$\mathrm{O}$ N A FIRST READING, MILTON'S PSYCHEDELIC PLOT BAFFLES AND BEMUSES. Multiple, contradictory and overlapping accounts of the same actions are frequently given; events often occur on four different levels simultaneously. ${ }^{1}$ Reading Milton for its plot can be an exercise in frustration. At times, the confusion of reading contributes to the power of the prophecy, for Milton is structured around a progressive commission of dramatic mistakes. The poem presents its visions as inspired errors; yet some errors seem more inspired-or at least more visibly thematized-than others. In the pages that follow, I will argue that gender and sexuality in particular run through the fabric of this prophecy as a frayed and contradictory strand. Milton claims that "The Sexual is Threefold: the Human is Fourfold"; ${ }^{2}$ the prophecy suggests with some consistency that to confuse humanity with the sexually differentiated state in which we find ourselves is to lose an entire dimension of perception, to find our senses contracted, limited to the realms of Beulah and Generation and shut out of Eden. Yet the poem offers a confused and confusing definition of "The Sexual," one which moves uneasily among biological sexes, gender roles and erotic attraction. ${ }^{3}$

I. As most readers willing to tackle Milton will know, these levels consist of: I) Eden, the realm of Eternity or human perfection; 2) Beulah, "evermore Created around Eternity" as a resting place for "all the weak \& weary / Like Women and Children" (3I:I-2); 3) Generation, the "vegetable world" in which we live; and 4) Ulro, a realm of materialist thought (like that of Bacon, Locke, Newton) and lifeless matter.

2. William Blake, Milton, a poem in 12 Books, plate 4:5. In The Complete Poetry and Prose of William Blake, eds. David Erdman and Harold Bloom (Berkeley: U of California P, I982). Future references to this edition will be noted parenthetically in the body of the text. References to Milton will be by plate and line number; references to other works such as $A$ Vision of the Last Judgment (VLJ) will be by page number.

3. I take these terms from Valerie Traub, "Desire and the Differences it Makes" in The Matter of Difference: Materialist Criticism of Shakespeare, ed. Valerie Wayne (Ithaca: Cornell UP,

SiR, 36 (Spring 1997) 
While Milton explicitly thematizes (and thus begins to correct) the limits of certain gendered stereotypes, other assumptions about gender or sexuality remain invisible, part of the poem's mechanics, its material base. Focusing on what remains opaque in relation to gender and sexuality should bring into stronger relief some of the political issues attendant on poetry structured as prophecy.

Let me begin with the most striking and perhaps least recognized error in the poem: Blake's address to Ololon in his garden at Felpham. First, a little history: Ololon as a name refers both to a river in Eden, and to a group of Eternals living on the banks of that river; misunderstanding Milton's mission, they drive his darkened image out of Eden. Realizing what they have done, they repent and descend in turn, taking on a variety of forms in the process: in Beulah, they appear as clouds (in which the Lord is visible); in Blake's garden (the world of Generation) they become a twelveyear old virgin. That virginal figure, answering Milton's call to self-annihilation, splits six-fold, and Ololon becomes in rapid sequence a dove, an ark, clouds of blood, streams of gore and finally a "Garment dipped in blood / Written within \& without in woven letters"; she becomes, in fact, "the Divine Revelation in the Litteral Expression." What exactly the reader is to make of this remains an open question.

In the midst of the kaleidoscopic transformations which structure Blake's prophecy, certain moments stand out as more accessible than others: Ololon's appearance in the garden at Felpham seems easier to grasp than most. The community of immortals takes on the form of a twelve-year-old virgin in a deliberate attempt at reassurance and alliance:

They could not step into Vegetable Worlds without becoming The enemies of Humanity except in a Female Form

And as One Female, Ololon and all its mighty Hosts

Appear'd: a Virgin of twelve years nor time nor space was

To the perception of the Virgin Ololon but as the

Flash of lightning but more quick the Virgin in my Garden

Before my Cottage stood for the Satanic Space is delusion

Walking in my Cottage Garden, sudden I beheld

The Virgin Ololon \& address'd her as a Daughter of Beulah [:]

I991). Abbe Blum drew my attention to Traub's piece; through her careful reading of an earlier draft she also helped pull this essay into sharper focus. 
Virgin of Providence fear not to enter into my Cottage What is thy message to thy friend: What am I now to do Is it again to plunge into deeper affliction? behold me Ready to obey, but pity thou my Shadow of Delight Enter my Cottage, comfort her, for she is sick with fatigue

$(36 / 40: 13-32)$

While Ololon could potentially appear as "the enemies of Humanity," they choose to avoid such a threatening form. Blake's illustration of this passage emphasizes its simplicity and accessibility: while most of the other designs in the poem feature close-ups of straining human bodies, this sketch presents a more distant child-like picture of a house, a garden, a man and descending angel (Figure I). After struggling throughout the poem to comprehend Blake's shifting models of overlapping worlds, the reader may find it a relief to return to the domestic space of a cottage garden-and a simpler mode of representation. Yet such relief may lead in turn to an error in judgment. The second book of Milton begins with the warning (engraved in mirror-writing about the title): "How wide the Gulf \& Unpassable! between Simplicity \& Insipidity." Is the design of Blake's garden to be judged simple or insipid? And what difference might this judgment make to a reading of the poem?

At first glance, the words addressed to Ololon by Blake's persona are as comforting as the design: he promises to do whatever is needed, asking only that this "Virgin of Providence" comfort his wife Catherine, his "Shadow of Delight." Blake specifically addresses Ololon as a Daughter of Beulah, a figure associated with encircling arms "of love \& pity \& sweet compassion" (30:12) but one incapable of withstanding the "exceeding unbounded" life (and mental strife) of Man [sic] in Eternity. Blake's mistake here seems to me quite astounding - so outrageous as to be almost selfparodic. Blake as poet and character alike is a prophet, a seer of visions; the poet concludes $A$ Vision of the Last Judgment with the following account of his powers:

What it will be Questioned When the Sun rises do you not see a round Disk of fire somewhat like a Guinea $O$ no no I see an Innumerable company of the Heavenly host crying Holy Holy Holy is the Lord God Almighty I question not my Corporeal or Vegetative Eye any more than I would Question a Window concerning a Sight I look thro it \& not with it. $(565-66)$

Yet the character Blake mistakes Ololon (an Innumerable company of the Heavenly host) for a Virgin and a Daughter of Beulah. While the second book of Milton is generally careful to mark the perceptual limitations of the vegetable world-the Lark and Wild Thyme of Felpham Vale are, for 


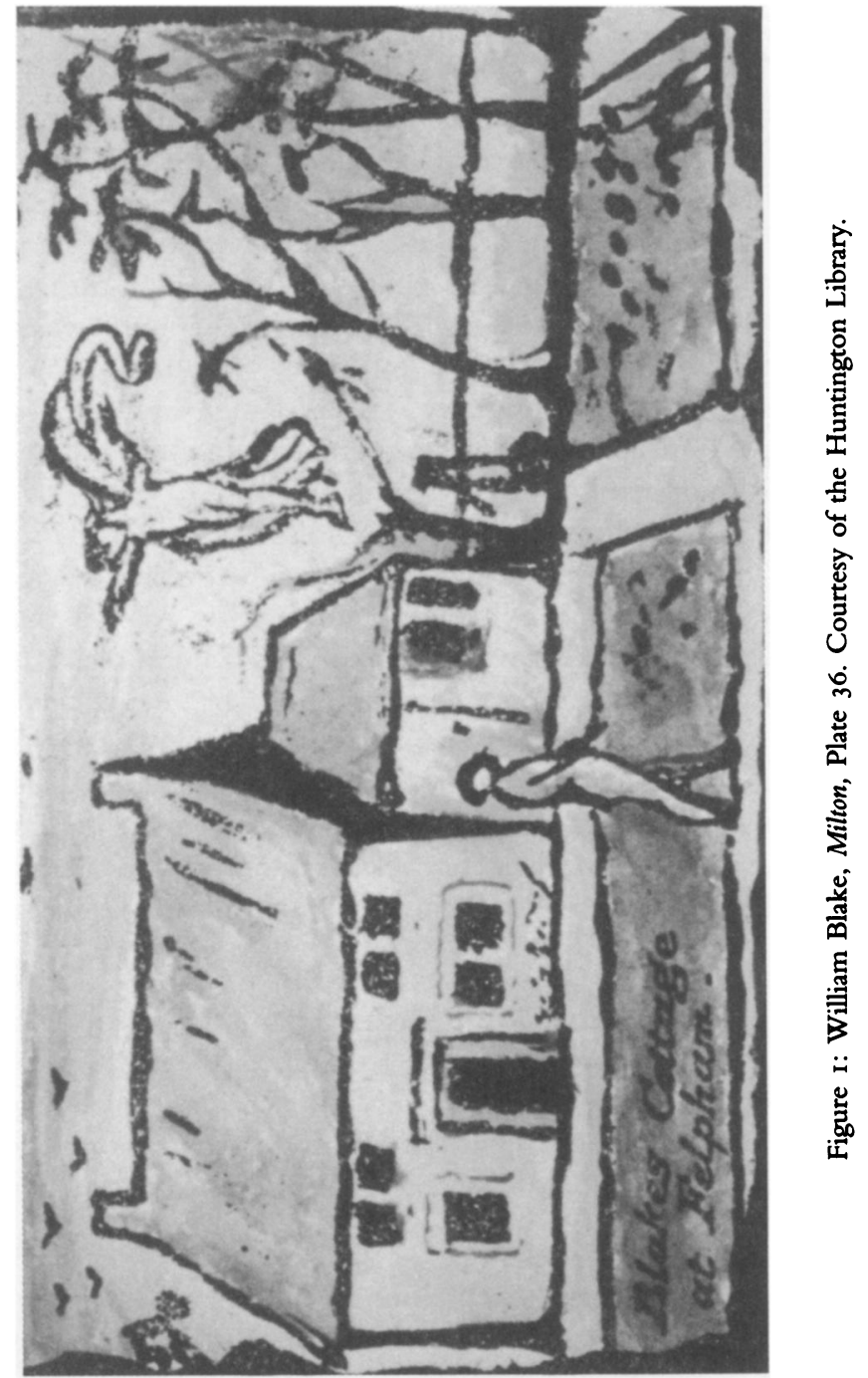

This content downloaded from 130.58.88.100 on Thu, 09 Jan 2020 14:19:51 UTC All use subject to https://about.jstor.org/terms 
instance, carefully translated back into mighty angels, the messengers of Los-Blake's persona apparently finds the female figure of Ololon so familiar, so transparently human, as to be unrecognizable in practice.

Blake's error is of course perfectly "natural": he mistakes himself for the hero of the poem (What am I now to do / Is it again to plunge into deeper affliction? behold me / Ready to obey"). On a rush of self-aggrandizement, he condescends to Ololon, sending her off to do the women's work of comforting the sick. Ololon does not accuse Blake of error, though 'she' does remind him of "[their] Act / In great Eternity which thou knowest!" Though Ololon describes 'herself' as "terrified," this terror does not seem to inhibit her action. ${ }^{4}$ "Mild was the voice, but more distinct than any earthly / That Miltons Shadow heard" (37:5): Ololon's response to Blake ("Knowest thou of Milton . . . him I seek!") functions as a call to which Milton responds by condensing all of his Fibres, appearing in Blake's Garden as a Cloud, a Human form, a Covering Cherub-a giant form uniting the many layers of Eden, Beulah, Generation and Ulro. Both in summoning Milton and in obeying his call to self-annihilation, Ololon seems the clearest hero of this last act of the prophecy. But this heroism, like Ololon her (their) self, can be difficult to recognize.

Blake's mistake makes visible the limits of his perceptions in this section of the poem: his partial blindness encompasses both Ololon and Milton. Milton too appears in a variety of forms on the various levels of the poem: in Eden, he is an "Image Divine tho' darken'd"; on the edge of Beulah, he enters into his Shadow, "a mournful form double; hermaphroditic." In Beulah, he appears as a wintry globe; in Generation (the vegetable world where Blake and his readers exist) he becomes a falling star, a part of Blake's foot (!) and a black cloud. Seeking his six-fold Emanation (a figure composed of his three wives and three daughters) Milton descends still further to Ulro, where his body appears as "the Rock Sinai"; yet his Human Shadow continues to travel in the Mundane Shell, a void outside of existence, until he actively confronts the demonized Urizen in the streams of Arnon. Trying to "place" Milton at any given moment in the poem is an extraordinarily complicated project, and the character Blake sees only the level of Generation clearly.

Following Milton's appearance, the poet-persona catalogues the mythical and historical figures included within the Miltonic Shadow. While this catalogue appears to encompass all of human history, its scope is notably limited to the forms of Generation and the figure of Satan: Blake sees each of the 27 Churches; he stands in Satan's bosom and views its desolations

4. By contrast, "Seeing Miltons Shadow, some Daughters of Beulah trembling / Returnd, but Ololon remaind before the Gates of the Dead" (34:47-48). 
at length-but Milton, as distinct from Satan, remains largely invisible in the terms of this catalogue. Ololon's vision seems more perceptive than Blake's: her description of Milton comes after the poet's challenge to Satan, ${ }^{5}$ and focuses on his divine aspect, his mission and his actions in other regions:

I see thee strive upon the Brooks of Arnon. there a dread And awful Man I see, oercovered with the mantle of years. I behold Los \& Urizen. I behold Orc \& Tharmas;

The Four Zoa's of Albion \& thy Spirit with them striving In Self annihilation giving thy life to thy enemies.

(40:4-8; my emphases)

The Blake-persona's description of Milton's Shadow extends for 79 lines of verse and contains five references to vision; Ololon's description of Milton is condensed into five lines, and contains four of the same references to vision. The poet's vision ranges widely yet lacks depth: Ololon's account goes straight to the heart of Milton's Self, yet remains so concise as to be incomprehensible to strictly mortal eyes and ears. Blake's (limited) observation of Milton's Shadow and Satan's bosom leaves him passive; Ololon's more comprehensive sight builds steadily toward an act of self-annihilation that brings Jesus himself into being and presages the harvest of the apocalypse. The figure Blake mistook for a Daughter of Beulah frightened of mental strife becomes "A Garment of War"; meanwhile, the would-be hero Blake trembles and faints, and then finds comfort at his side in the form of his "sweet Shadow of Delight." The two women discounted by Blake appear as strong or, in the case of Ololon, far stronger than the poet himself.

What are the consequences of Blake's "misreading" of Ololon? The action of the poem seems to continue unchecked, which would suggest the mistake is minor. Yet it throws serious doubt on the effectiveness of the prophecy, the quality of its reception. The poet-persona can visualize the entire vegetable world as a sandal to strap on and walk through eternity: if even he is so drastically limited in his vision and his understanding of the actors in this drama, what hope is there for less privileged readers? Indeed, some critics celebrate what I am calling the crowning error of the poem: in the process, they underestimate Ololon and overestimate the character Blake. According to Harold Bloom, for instance, "Blake now enters into the dignity of his final role in the poem, which is to the seer of the Miltonic Great Marriage. . . . The dialogue between Ololon

5. In sequence and presumably in time, though one is hesitant to make claims about chronology in this poem. 
and Blake is worthy of the occasion." ${ }^{6}$ Along the same lines, G. E. Bentley described Plate 4I of Milton in the following terms: "The whole plate is a very dark design of a naked man whose head gives off light supporting a kneeling, dropping, White-haired figure in a long robe. The naked man seems to be standing in a river or small lake" (Figure 2). ${ }^{7}$ He then goes on to suggest that this plate may represent the line "Before Ololon Milton stood" (42:I). Bentley's suggestion ignores several of his own observations: the white hair of the figure and the river in which the naked man stands. It seems to me far more plausible that the plate represents a scene just preceding the plate: "Urizen faints in terror striving among the Brooks of Arnon / With Miltons Spirit" (40:53). Only an assumption of female passivity and weakness supports Bentley's preferred reading. Unfortunately, the poem provides plenty of material to support such an assumption.

2

Milton's confusion over gender and eroticism intersects in complicated ways with Blake's attempt to replace or redeem Greek and Roman models of epic poetry. A large part of Blake's dislike for such models derives from the physical violence, or "corporeal war," these earlier epics detail and encouraged. The Preface to Milton, for instance, describes Greeks and Romans as "silly ... slaves of the Sword"; Milton himself in announcing his descent is brought to complain that "the Nations still / Follow after the detestable gods of Priam; in pomp / Of warlike selfhood, contradicting and blaspheming" (I4-I6). Again in the Preface to Milton, Blake claims, "We do not want either Greek or Roman Models if we are but just \& true to our own Imaginations, those Worlds of Eternity in which we shall live for ever; in Jesus our Lord." "Want" here should perhaps be read as a lack: "there will be no lack of Greek and Roman models if we are but just \& true to our own Imaginations." Milton contains elements of various Greek (if less clearly Roman) models, appropriated with varying degrees of success. But the central model for the poem is of course Paradise Lost, itself "infected by the general malady" of warlike selfhood. Blake eventually modifies his attack on Greek if not Roman models; in $A$ Vision of the Last Judgment he announces: "Let it here be Noted that the Greek Fables originated in Spiritual Mystery \& Real Vision ... The Nature of my Work is Visionary or Imaginative it is an Endeavour to Restore <what the Ancients called $>$ the Golden Age" (5s5). Blake's later prophecies work to redeem the warlike models of Greece (and Paradise Lost) by translating corporeal war into an epic of intra-psychic transformation.

6. Harold Bloom, Blake's Apocalypse (New York: Doubleday, 1963) 352-\$3.

7. G. E. Bentley, Jr., ed., William Blake's Writings (Oxford: Clarendon, I978) I: 407-8. 


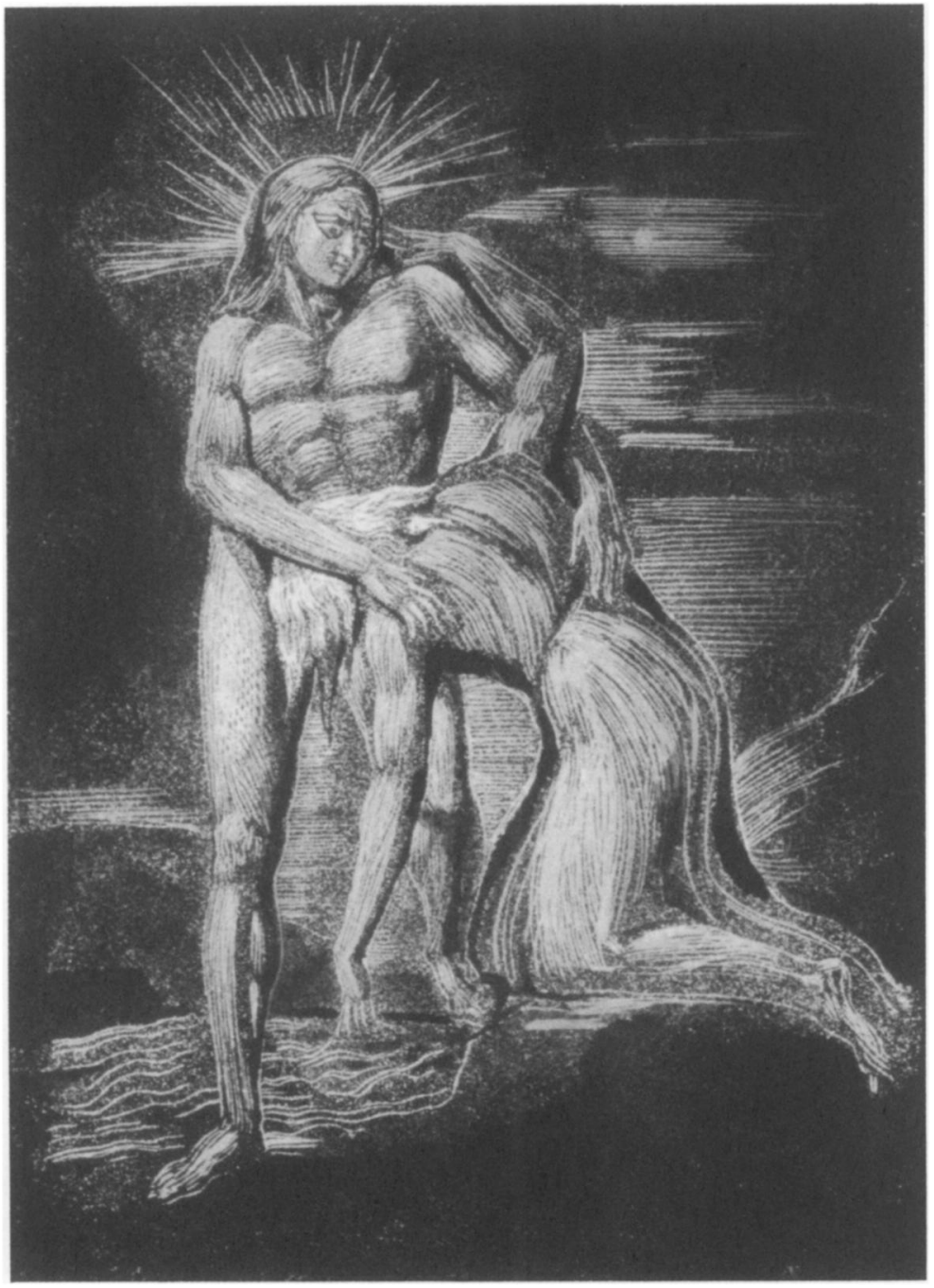

Figure 2: Milton, Plate 4I. Courtesy of the Huntington Library.

This content downloaded from 130.58.88.100 on Thu, 09 Jan 2020 14:19:51 UTC All use subject to https://about.jstor.org/terms 
Redemption, however, seems far from secure. Blake's exploration of intrapersonal conflict or strife tends to take shape around questions of gender roles, biological sex and erotic connections. These three categories are interwoven throughout Milton in odd and anxious but fairly consistent ways, producing I) a radical constriction and devaluation of feminine gender roles, 2) the doubled figure of the hermaphrodite and 3) repeated suggestions of homoeroticism at key moments in the text. Why should an attempt to unravel warlike Selfhood and the slavery of the sword produce the sexual miscellany of homoeroticism, hermaphrodites and misogyny? Blake's engagement with determinate biology in the figure of the hermaphrodite seems in context an attempt to free erotic energy for radical political purposes, but because that biology continues to rely on and defend fixed gender definitions, the politics of the poem become distinctly skewed. Not surprisingly, the torque of Milton's sexual politics seems to gravitate around the elements of Paradise Lost at play within Blake's later epic. Thus in order to trace the transformation of corporeal war into an oddly syncopated war among the sexes, I want to focus first on two moments in which Milton invokes Paradise Lost: the first episode uses elements of Paradise Lost to rewrite an earlier creation myth; the second episode offers its own revision of Satan's expulsion from heaven.

Milton begins with a Bard's song which presents three different stories of creation: the first describes a world "Indefinite and Opake" taking shape as Urizen's ghastly body. The second tale tells of strife among the Eternals as Los's sons squabble over who has the better job: Satan the Miller and Palamabron the Harvester switch places for a day through Satan's urging, and both create chaos out of the other's job. This leads to accusations, to mourning, to battle (in which an apparently innocent party, Thulloh, is killed) and finally to judgment by an Assembly of the Eternals. Rintrah, the only son not involved in the original dispute is mysteriously held to blame; Satan nonetheless becomes furious and disowns his family, becoming opaque-in this moment, Los and Enitharmon recognize Satan as Urizen, marking the way both stories of creation reach the same conclusion.

Leutha, Satan's Emanation, comes forward to redeem him by offering a third version of this creation myth. Lusting after Palamabron but frightened off by his emanation Elynittria, Leutha persuades Satan to take over Palamabron's Harrow, so that she herself may play the role of Elynittria. Unfortunately, neither Leutha nor Satan is up to the challenge of the Harrow, and chaos ensues-at which point, Satan disowns his Emanation and becomes opaque. Enitharmon creates a space to protect Satan; Elynittria, having been scolded by Los for jealousy, brings Leutha to Palamabron's tent, where the former gives birth to Death and to Rahab, the female figure 
known elsewhere in Milton as Virgin Babylon Mother of Whoredoms. This conclusion to the Bard's Song gives the third creation story more weight, for it extends history beyond the point reached by the earlier two myths: Death and Church history take shape only in this final story. The Bard's Song ends and the Bard's audience, an Assembly of Eternals, question his truth and his sources. Claiming the truth of Inspiration, the Bard takes refuge in Milton's bosom - and Milton promptly announces his descent.

These three creation myths might be read, respectively, as perverse renditions of central Blakean texts: Genesis, Hesiod's Theogony ${ }^{8}$ and Milton's Paradise Lost. In Genesis 2, verses 6 and 7, "there went up a mist from the earth, and watered the whole face of the ground. And the Lord God formed man of the dust of the ground, and breathed into his nostrils the breath of life; and man became a living soul." Milton's opening offers a grotesque parody: "Hanging upon the wind, Two Nostrils bent down into the Deep / And a fifth Age passed over \& a State of dismal woe" (3:20-2I). Hesiod's Theogony presents the struggles of the gods: Blake presents the squabbles of the divine family. Not surprisingly, however, it is the third account which seems to have the strongest impact on the listening Milton. Leutha's tale, introduced with the claim, "I am the Author of this Sin!" (I I:35), rewrites the physical battles of the Divine Family as a story of frustrated sexual desire - and in that rewriting quotes directly from Paradise Lost.

At first glance, the conflict among brothers appears to have been translated into a story of heterosexual desire: a tale in which female jealousy is the culprit. Yet the terms of that translation produce, at least metaphorically, the uncanny figure of the hermaphrodite, reintegrating female jealousy back into a male psyche:

She spake: I am the Author of this Sin! by my suggestion My Parent power Satan has committed this transgression.

I loved Palamabron \& I sought to approach his Tent, But beautiful Elynittria with her silver arrows repelld me.

For her light is terrible to me. I fade before her immortal beauty.

O wherefore doth a Dragon-form issue from my limbs

To sieze her new born son? Ah me! the wretched Leutha!

(I I:35-I 2:3)

8. "Hesiod's Theogony [was a] work Blake admired and one that provides the best introduction to the large design of Blake's own mythology" (Joseph Anthony Wittreich, Jr. "Opening the Seals: Blake's Epics and the Milton Tradition" in Blake's Sublime Allegory, eds. Stuart Curran and Joseph Anthony Wittreich, Jr. [Madison: U of Wisconsin P, I973] 246); this is a claim to which I shall return. 
"She spake" marks the public formality of this speech before the assembly: the near rhyme between suggestion and transgression make the lines seem perhaps a bit too pat, a bit too carefully constructed. And indeed the heterosexual frame of this story rapidly begins to seem an artificial construct. Leutha's greatest sin appears to be her meddling with Satan's gender:

entering the doors of Satans brain night after night Like sweet perfumes I stupefied the masculine perceptions And kept only the feminine awake; hence rose his soft Delusory love to Palamabron: admiration join'd with envy Cupidity unconquerable! my fault, when at noon of day The Horses of Palamabron call'd for rest and pleasant death: I sprang out of the Breast of Satan, over the Harrow beaming In all my beauty! that I might unloose the flaming steeds As Elynittria use'd to do; but too well those living creatures Knew that I was not Elynittria, and they brake the traces But me, the servants of the Harrow saw not: but as a bow Of varying colours on the hills; terribly rag'd the horses

Leutha seduces Satan into femininity, in part to keep herself from murdering Elynittria's first-born son: an act, perhaps, of masculine aggression. What first appeared as Satan's (suspect) homoerotic attraction to Palamabron is presented more essentially as female heterosexual desire. Yet this revision of homoeroticism toward heterosexual desire produces as its byproduct the figure of Satan as a hermaphrodite: female and male in one body, its masculinity overwhelmed by femininity gone out of control. This hermaphrodite is a contradiction in terms: delusion bound to love, admiration to envy. The desire to drive the Harrow appears in this context to have been Leutha's rather than Satan's: still, all goes well until Leutha tries to play Elynittria's part. The emphasis on Elynittria's power and glory, both in this passage and the previous one, suggests that Leutha desires Palamabron less than she desires the place held by the "Shadow of his Delight": Elynittria herself. As she fails to take Elynittria's place, Leutha appears on the scene not in propria persona, but as a rainbow over the hills-the symbol of an old covenant which fails to hold. Milton may begin with a call to move beyond the models of corporeal war presented by Greek and Roman literature, yet at this moment in the poem, interpersonal antagonism and unacknowledged aggression and desire seem to infect even the Judeo-Christian image of a truce between God and humans.

Precisely at this moment, when aggression revises what might be called the Christian epic of history, Blake presents his most explicit allusion to 
Paradise Lost. The horses having run out of control, Leutha forms the Serpent in an attempt to regain command:

To do unkind things in kindness! with power armd, to say

The most irritating things in the midst of tears and love

These are the stings of the Serpent! thus did we by them; till thus

They in return retaliated, and the Living Creatures maddend.

The Gnomes labourd. I weeping hid in Satans inmost brain;

But when the Gnomes refus'd to labour more, with blandishments

I came forth from the head of Satan! back the Gnomes recoil'd.

And call'd me Sin, and for a sign portentous held me.

Compare Sin, addressing Satan in Paradise Lost:

Then shining heav'nly fair, a goddess armed

Out of thy head I sprung: amazement seized

All th'host of heav'n; back they recoiled afraid

At first, and called me Sin, and for a sign

Portentous held me; but familiar grown,

I pleased, and with attractive graces won

The most averse, thee chiefly. ${ }^{9}$

Where Paradise Lost presents Sin as an Athena-figure, a "goddess armed," Leutha seems little more than an incompetent. Yet she too is armed, and her weapons are the more vicious for being less visible: "to say / The most irritating things in the midst of tears and love" is enough to madden any living creature. The gnomes also enter into battle with these new weapons: what Leutha has produced is a full-flown war of words, which leads in the end to Satan's descent to Eternal Death. One wonders how much of an advance on Greek, Roman and Miltonic models this really is.

In Milton's epic, Satan spawns Death by incestuously coupling with his daughter Sin; Leutha (Sin) breeds Death not with Satan, but rather in dallying with Palamabron, thus fulfilling one part of Blake's Vision of the Last Judgment:

In Hell all is Self Righteousness there is no such thing there as Forgiveness of Sin . . Forgiveness of Sin is only at the Judgment Seat of Jesus the Saviour where the Accuser is cast out. not because he Sins but because he torments the Just $\&$ makes them do what he condemns as $\operatorname{Sin} \&$ what he knows is opposite to their own Identity ( $V L J 565$ )

9. John Milton, Paradise Lost, ed. Scott Elledge (New York: Norton, 1975) 2.757-63. Future references to Paradise Lost will be to this edition and will be noted parenthetically in the text. 
Satan torments Palamabron (the Just) \& makes him do what he (Satan) condemns as $\operatorname{Sin} \&$ what he knows is opposite to Palamabron's own Identity. In this version of the story, Palamabron takes on Satan's Sin (as a lover), becoming complicit in the creation of Death, though this is opposite to his own identity. Milton, having heard this revised story of "impious war in heaven," exclaims,

What do I here before the Judgment? without my Emanation?

With the daughters of memory, \& not the daughters of inspiration?

I in my Selfhood am that Satan: I am that Evil One!

The second line could be taken as a comment on the story he's just heard: this is a mangled tale, he might protest - badly constructed from bits and pieces of his own writing, and clearly uninspired. W. J. T. Mitchell has argued persuasively that Leutha's attempt to ransom Satan models for Milton the necessity of his descent. ${ }^{10}$ Yet while Leutha does in some ways show Milton what he must do, that demonstration may be less a matter of modelling for Milton the act of Ransom and more a matter of showing Milton the horror he (in the figure of the hermaphroditic Satan) has become. Leutha claims authorship of Sin even as she quotes lines authored by Milton; the poet may be forced to descend simply in order to rewrite and reclaim his text.

In this episode of the prophecy, rewriting war as sexual conflict and delusion produces not one but two hermaphrodites. Satan's apparent homoeroticism is rewritten as female (heterosexual) desire which is also the Blakean female will: Satan, controlled by his Emanation Leutha, is the first hermaphrodite. But Leutha is also powerfully focused on Elynittria, whose beauty makes her fade: one might read this as an instance of female homoeroticism. When Leutha, failing in her attempt to "be" Elynittria, springs out of Satan's head, she becomes a figure like Athena, a masculine goddess - in certain versions of classical mythology, another hermaphrodite.

Condemnation of female characters accompanies the figure of the hermaphrodite. While Leutha's confession and attempt to ransom Satan evoke sympathy, nonetheless her actions are shown to have been at the root of the battle between Satan and Palamabron and among their various followers. Even after she has confessed and been forgiven, her actions (which seem limited to the sexual) serve only to produce the figure of Death on the one hand and Rahab and Tirzah (also associated with hermaphrodites) on the other. Leutha is the figure of the stereotypical "bad woman" in the

Io. W. J. T. Mitchell, "Blake's Radical Comedy: Dramatic Structure as Meaning in Milton" in Blake's Sublime Allegory 293. 
Bard's Song, but even the "good woman" Elynittria is shown to be responsible for the evil events recounted: protecting Palamabron from Leutha is indirectly responsible for the war in heaven; giving Leutha to Palamabron leads to natural religion, cruelty and death for those within Satanic space. Elynittria is damned if she does and damned if she doesn't: whatever action she takes leads to death and destruction.

The tale Leutha authors revises the creation story of the Theogony in the direction of Paradise Lost, but this first move away from Greek and Roman models merely blames conflict and strife on the women involved in the story. The fact that 'good' and 'bad' women seem equally culpable underlines the functional role of their responsibility as it echoes the feminization of error (through the figures of Sin and Eve) in Milton's story of the fall. Blake's first metaphoric invocation of the hermaphrodite disrupts this straightforward assigning of blame as it disrupts a one-to-one equation of body and (sexual) identity. Leutha's desire seems remarkably freefloating, capable of invading and overwhelming Satan's perceptions-even her body moves in and out of his without reference to physical constraint. Yet her authorship of sin seems as open to dispute as Satan's authority for action and self-justification. Where two are one, responsibility and authority appear confused and partial concepts.

This first, largely metaphoric invocation of the hermaphrodite gives way later in the poem to far more concrete references-but the figure of the hermaphrodite continues to appear in relation to the fall of man, as refigured by Satan's expulsion from heaven and Milton's descent. ${ }^{11}$ Milton's descent to Eternal Death begins with an entry into hermaphrodite form:

I I. If the Bard's Song rewrites the struggles of the theogony into the sexual fall of Paradise Lost, the body of the prophecy (and this prophecy has more of a "body" than most texts) rewrites Milton's version of the expulsion of Satan from heaven. In Paradise Lost, Lucifer is said to have been cast out of heaven by his own pride (1.36-37):

He trusted to have equaled the Most High,

If he opposed; and with ambitious aim

Against the throne and monarchy of God

Raised impious war in heav'n and battle proud

With vain attempt. Him the Almighty Power

Hurled headlong flaming from th'ethereal sky

With hideous ruin and combustion down

To bottomless perdition, there to dwell

In adamantine chains and penal fire,

Who durst defy th'Omnipotent to arms.

$(40-49)$

In Milton, of course, it is Milton himself who is driven out of Eden by the Eternals living on the banks of the river Ololon. Blame rests with the Eternals rather than with Milton: they are "Drunk with the Spirit, burning round the Couch of death"; "wrathful, fill'd with 
Then on the verge of Beulah he beheld his own Shadow;

A mournful form double; hermaphroditic: male \& female

In one wonderful body. and he entered into it

In direful pain for the dread shadow, twenty-seven-fold

Reached to the depths of direst Hell, \& thence to Albions land:

Which is this earth of vegetation on which now I write.

The twenty-seven "folds" of this double-sexed Shadow are enumerated in the character Blake's vision of the twenty-seven Heavens and their Churches:

Adam, Seth, Enos, Cainan, Mahaleleel, Jared, Enoch, Methuselah, Lamech: these are Giants mighty Hermaphroditic Noah, Shem, Arphaxad, Cainan the second, Salah, Heber, Peleg, Reu, Serug, Nahor, Terah, these are the Female-Males A Male within a Female hid as in an Ark \& Curtains, Abraham, Moses, Solomon, Paul, Constantine, Charlemaine Luther, these seven are the Male-Females, the Dragon Forms Religion hid in War, a Dragon red \& hidden Harlot

All these are seen in Miltons Shadow who is the Covering Cherub.

(37:35-44)

Within Milton's Shadow or Satan's opacity, the Churches have been subdivided into three groups of hermaphroditic forms. First, figures from before the Flood appear as "Giants mighty Hermaphroditic." Figures associated with Biblical history, the period of Blake's second patriarchs, are represented as "the Female-Males / A Male within a Female hid as in an Ark \& Curtains." The third group of figures, associated with the often military spread of organized religion, appear by contrast as "the MaleFemales, the Dragon Forms / Religion hid in War, a Dragon red \& hidden Harlot." These three kinds of hemaphrodites are oddly central to the events occurring in Felpham Vale: Milton descending into Blake's garden is indeed a giant form hermaphroditic, "Reaching from heaven to earth a

rage!", they create needless destruction, rending "the heavens round the Watchers in a fiery circle" $(20: 44-46)$. Yet these spiritual drunkards are quick to see their error and repent, though the source of their enlightenment remains obscure to the reader. Indeed, Ololon laments for "seven days of Eternity" before the cause of lamentation is finally specified: "they lamented that they had in wrath \& fury \& fire / Driven Milton into the Ulro; for now they knew too late / That it was Milton the Awakener" (2I:3 I-33). One wonders what they thought Milton was to begin with: the poem specifies that "they stood / Looking down into Beulah" before rending the heavens. The masculine multitudes of Ololon may have experienced Leutha's sexual jealousy-but this is merely implied rather than clearly stated. 
Cloud \& Human form" (37:14). Rahab, also known as Mystery Babylon or religion hid in war, dwells in the striking desolation of Satan's bosom, constituting both in herself and in conjunction with Satan a male-female hermaphrodite. Finally, Ololon (a mirror image of Rahab Babylon) literalizes the second, female-male version of hermaphroditism: she (re)descends to Felpham's Vale "as a moony Ark" (42:7), thereby replacing the simile, "A Male within a Female hid as in an Ark \& Curtains" with the (poetic) actuality of a moony Ark which becomes the covering (curtain) of a garment dipped in blood.

Milton's Paradise Lost complicated Greek-style myths of war in heaven with the sexual politics of a fall from grace, intensifying the familiar association of sex and war already present in Greek and Roman models. But Blake's epic chronology insists that sexual reconfiguration of war in heaven has been complemented in historical terms by religious war on earth. Within this chronology, the hermaphrodite becomes an epic image for the confusion of religion and war-and its alienating effects. Where erotic energy joins separate bodies together in sexual consummation, the hermaphrodite displays two sexes at odds in a single body. Blake's use of the hermaphrodite seems more than purely metaphoric or coincidental: in the eighteenth century more generally, this biologically coded figure marked a point of slippage between political disruption and physical identity. According to Randolph Trumbach, for instance, the eighteenth century marked a gradual transition from a system centered around two genders (male and female) and three sexes (men, women and hermaphrodites) to a system including four genders (heterosexual men and women and homosexual men and women) and two sexes (male and female). At the beginning of the century,

sodomitical acts contravened the gender system only when they violated the patriarchal code, that is when adult men allowed themselves to be penetrated and when women penetrated women. Because there was no third gender to which to assign individuals who inverted the patriarchal order in their sexual acts by penetrating or being penetrated in violation of their gender status, such persons were likely to be classified as hermaphrodites, that is as biologically deviant. In men, this classification was sometimes understood to be symbolic, but in the case of women, they were likely to be examined by doctors for signs of actual clitoral enlargement. ${ }^{12}$

The hermaphrodite thus provided an image for deviance at once sexual and political-a deviance for which biological grounding seemed more

12. Randolph Trumbach, "London's Sapphists: From Three Sexes to Four genders in the Making of Modern Culture" in Body Guards: The Cultural Politics of Gender Ambiguity, eds. Julia Epstein and Kristina Straub (New York: Routledge, I99I) I 14. 
essential for women than for men. Over the course of the century, sexual behavior comes to be discussed more in terms of two sexes, (male and female), two "normal" genders (heterosexual men and women) and two deviant genders (the molly and the tommy, or in upper-class terms, the sodomite and the sapphist). Yet the development of a deviant female gender (the sapphist) lagged behind that of the male: sapphism was slower to be named, described, recognized. The metaphorical use of "hermaphrodite" for men shifted relatively quickly towards the use of the term sodomite or molly; while "hermaphrodite" was sometimes applied to women in a metaphorical sense at the beginning of the century, "its purpose was usually to stigmatize female clothing that seemed to impinge on the male domain" [Trumbach II6-I7]. The turn to biology in explaining female sexual deviance led to a strong association of hermaphroditism with female biology: not that all women were hermaphrodites, but for writers such as James Parsons, all hermaphrodites were likely to be women. ${ }^{13}$ Other writers warned that mutual masturbation in young girls "would result in the enlargement of the clitoris and that this might eventually cause them to be classified as hermaphrodites" [Trumbach 118]. The figure of the hermaphrodite could thus be used to stigmatize women's use of "masculine" clothing and female homoeroticism, even when the latter did not include penetration.

The asymmetry between male and female hermaphroditism and the link between charges of female hermaphroditism and masculine dress are both central to Blake's deployment of the figure. He privileges hermaphroditism imagined as a male-within-a-female (forerunner of the tommy or sapphist), and devalues that of a female-within-a-male (forerunner of the molly or sodomite). At the same time, however, Blake also privileges male homoeroticism, and presents the transformative potential of the hermaphrodite as depending upon the (politically conservative) relations established between its male and female parts. Within Milton, militarized religion and warlike Selfhood can be superseded only through the transformation of Milton's relation to his female Emanation. Such a transformation depends both on Milton's willingness to seek out and redeem his Emanationand on Ololon's willingness to accept a subordinate role in relation to Milton, 'her' willingness to take on the eccentric and external role of the garment.

The end of the prophecy rewrites Ololon's expulsion of Milton from Eden into an (apparently) less threatening confrontation between man and woman. Both Ololon and Milton can be seen as hermaphroditic forms (Milton a "giant form hermaphroditic," Ololon a neuter virgin composed

13. James Parsons, A Mechanical and Critical Inquiry into the Nature of Hermaphrodites (London, 174I). 
of male multitudes in Eden), yet their confrontation is staged not only as a struggle for self-recognition and understanding, but also as a battle between the sexes. The prophecy claims that Ololon "could not step into Vegetable Worlds without becoming / The enemies of Humanity except in a Female Form"- though the logic behind this claim is never elucidated. Ololon (first a plural then once again a female figure) gradually "recognize/s" the form they themselves have unwittingly taken on and the space in which they find themselves. Specifically, Ololon describe themselves as a female form, and as a contrary to Milton's masculinity: "Is this our Femin[in]e Portion the Six-fold Miltonic Female / . . . are we Contraries O Milton, Thou \&I?" [4I:30-35]. As male and female figures, Milton and Ololon can more clearly be seen as contraries: this recognition of sexual opposition undoes the necessity of war, which now can be presented as a mistake, almost as an accident. "O Immortal! how were we led to War the Wars of Death"? [4I:36] This recognition also transforms the "Void Outside of Existence" into "a Womb"-but the womb is also the (masculine) "Death Couch of Albion" (4I:37-42:I).

To move beyond these deathly forms, Ololon is asked to recognize and acknowledge her/their contribution to the figure of the Covering Cherub-a recognition which will lead in turn to a demand for self-annihilation. In dialogue with Milton, Ololon defines herself as the paradoxical cause of violence, having produced in multiple human forms the "absurdity" of Natural Religion and the cruelty associated with moral virtue. This self-definition remains inseparable from the figure of the hermaphroditic female-within-the-male:

Are those who contemn Religion \& seek to annihilate it Become in their Femin[in]e portions the cause and promoters Of these Religions, how is this thing? This Newtonian Phantasm This Voltaire \& Rousseau: this Hume \& Gibbon \& Bolingbroke

This Natural Religion! this impossible absurdity

Is Ololon the cause of this? O where shall I hide my face?

These tears fall for the little-ones: the Children of Jerusalem

Lest they be annihilated in thy annihilation.

No sooner had she spoke but Rahab Babylon appeard Eastward upon the Paved work across Europe \& Asia Glorious as the midday Sun in Satans bosom glowing: A Female hidden in a Male, Religion hidden in War Namd Moral Virtue; cruel two-fold Monster shining bright A Dragon red \& hidden Harlot which John in Patmos saw.

$(40: 9-22)$ 
The first of these stanzas implicitly presents a series of hermaphrodites: Newton, Voltaire, Rousseau, Hume, Gibbon and Bolingbroke are men considered in their "feminine portions": this combination of masculinity and femininity comprises Natural Religion as an impossible absurdity. The second stanza frames that impossible absurdity as a female character Rahab (herself a hermaphrodite: the feminine portion of the preceding list of names) within a male: Satan. The figure of the hermaphrodite is inwardly doubled: a "two-fold Monster" seen by a male prophet, John in Patmos. Ololon's self-indictment exposes the symbolic contradiction of sceptical philosophy and moral virtue. The desire to hide 'her' face is spoken rather than acted out: Ololon's articulation of shame and responsibility means Rahab can no longer remain hidden in Satan. Yet Ololon's rejection of this contradiction reinscribes her as female as she weeps over the Children of Jerusalem.

Ololon's articulation of her/their faults presents a self-indictment parallel to (though more extended than) Milton's earlier acknowledgment " $I$ in my Selfhood am that Satan!" The act of self-annihilation appears at first an equally symmetrical endeavor. Milton commands Ololon with "terrible majesty" to follow his example:

Obey thou the Words of the Inspired Man

All that can be annihilated must be annihilated

That the Children of Jerusalem may be saved from slavery

There is a Negation, \& there is a Contrary

The Negation must be destroyd to redeem the Contraries

The Negation is the Spectre; the Reasoning Power in Man

This is a false Body: an Incrustation over my Immortal

Spirit; a Selfhood, which must be put off $\&$ annihilated alway

To cleanse the Face of my Spirit by Self-examination.

To bathe in the Waters of Life; to wash off the Not Human

I come in Self-annihilation \& the grandeur of Inspiration.

(40:29-4I:2)

It's not entirely clear from this speech which of Milton's words are to be obeyed, for rather than giving instructions to Ololon, he describes the actions he himself should take. Satan has been described as Milton's Spectre: this then is the Negation, the false Body, the Incrustation which must be put off. Milton shows Ololon what to do by his own example. Yet Satan, last seen thundering on the stormy sea, is never clearly put off, never clearly annihilated: he simply remains unmentioned through the remainder of the poem. And the prophecy represents Ololon's and Milton's separate experiences of self-annihilation in strikingly asymmetrical terms. 
Ololon's self-annihilation seems by far the more explicit: the figure of the virgin divides into six parts "with a shriek / Dolorous that ran thro all Creation" and disappears into the depths of Milton's shadow. What remains of Ololon then takes on a series of non-human forms: an ark, clouds of blood, streams of gore and finally a "Garment dipped in blood" which is itself a "litteral expression" of divine revelation. Self-annihilation figured as loss of virginity seems at best an experience of violence, a loss of autonomy and agency. Milton's self-annihilation, by contrast, seems far more gradual, peaceful and creative. His image of self-annihilation as "bath[ing] in the Waters of Life" both recalls and revises Urizen's attempt to baptize Milton in the icy waters of the Jordan. Milton's response is that of the sculptor-artist: he humanizes the demon Urizen by reshaping his figure with warm clay.

Silent they met, and silent strove among the streams, of Arnon Even to Mahanaim, when with cold hand Urizen stoop'd down And took up water from the river Jordan: pouring on To Miltons brain the icy fluid from his broad cold palm. But Milton took of the red clay of Succoth, moulding it with care Between his palms: and filling up the furrows of many years Beginning at the feet of Ruizen, and on the bones Creating new flesh on the Demon cold, and building him, As with new clay a Human form in the Valley of Beth Peor.

(I 8:5I-I9:14)

Silent Milton stood before

The darkend Urizen; as the sculptor silent stands before His forming image; he walks round it patient labouring.

These passages undo the not-Human by a process of addition and accretion, rather than the casting off described to Ololon, or even the washing off described in 41:2. Milton's silence marks the absence of Ololon's "shriek / Dolorous"-but whether this suggests his greater self-control or her greater suffering is difficult to determine. The moment of self-annihilation in this struggle between men ("one giving life, the other death / To his adversary" [19:29-30]) seems to come when "Urizen faints in terror striving among the Brooks of Arnon / With Miltons Spirit" (39:53-54). Blake draws attention to this moment with the image (already discussed) of plate 4I; the fact that Bentley reads this image as a figure of the female Ololon highlights the potentially erotic connection between the two men. The "great Miltonic marriage" Bloom envisions occurring between Milton and Ololon is not much of a marriage- the two figures never touch as man 
and woman - they come together only as Jesus and the garment of God. Yet Milton and the fainting Urizen do in fact touch: in this moment of surrender, Milton supports the humanized Urizen, whose icy, stony façade is finally undone. If a marriage occurs in Milton, it is not the heterosexual union of contraries, but rather an intensification of similarities: Milton announces that he himself is Satan, whom Los and Enitharmon have already recognized as Urizen. Milton striving with Urizen reshapes himself in Human form. At the same time, however, this re-union of the self is framed as a homoerotic attraction of opposite types: the redeemed and the elect who meet on Albion's hills. And after Ololon's transformation into the non-human forms of ark and bloody garment, Milton joins with the Starry Eight to become "One Man," the figure of Jesus. The act of self-annihilation is thus profoundly asymmetrical: Ololon, a female (and a) hermaphrodite, vanishes, sublimated into symbols surrounding the masculine figure of Jesus - a figure produced by the intensification, the homoerotic doubling of the male (and hermaphroditic) subject. ${ }^{14}$

The asymmetry between Ololon and Milton turns on a rough equation of femininity with forms of clothing-covering and revelation at onceand of masculinity with humanity. Milton's call to self-annihilation returns repeatedly to degraded examples of the garment imagery that resounds throughout the poem:

To cast off Rational Demonstration by Faith in the Saviour

To cast off the rotten rags of Memory by Inspiration

To cast off Bacon, Locke \& Newton from Albions covering

To take off his filthy garments, \& clothe him with Imagination

The clothing motif vanishes into talk of Poetry, State Government and moral hypocrisy, only to return in the closing lines of this address:

These are the Sexual Garments, the Abomination of Desolation

Hiding the Human Lineaments as with an Ark \& Curtains

Which Jesus rent: \& now shall wholly purge away with Fire

Till Generation is swallowed up in Regeneration.

Ololon's response suggests that these sexual garments are specifically associated with female sexuality. ${ }^{15}$ They progress (in 'her' voice) from a recog-

14. Yet while Milton is presented as a male hermaphrodite within the realm of Generation, this feature of his generated body seems to be ignored at the crucial moment of self-annihilation.

I5. Various critics have noted the prevalence of garment imagery in the poem, but usually in gender neutral terms. Harold Bloom remarks, for instance, that "[i]f there is a single central image in Milton, it is the garment, from the weavings of Enitharmon's looms that cover the 
nition of "our Femin[in]e Portion the Six-fold Miltonic Female" to an acceptance of partial responsibility for gendered violence ("O Immortal! how were we led to War the Wars of Death"?) to a self-purging of (virgin) femininity:

So saying, the Virgin divided Six-fold \& with a shriek Dolorous that ran thro all Creation a Double Six-fold Wonder!

Away from Ololon she divided \& fled into the depths

Of Miltons Shadow as a Dove upon the stormy Sea.

Ololon's subsequent forms suggest how difficult Blake found it to purge "Sexual Garments" from "Human Lineaments." Once the figure of the virgin has been annihilated, rather than taking on other human forms, becoming capable of experiencing and "authoring" revelation, Ololon is all the more firmly equated with the role of (bloody) garment, upon which revelation is "litterally" written. Thus while Blake's first, largely metaphoric invocation of hermaphroditism serves to unsettle assumptions of female responsibility for humanity's fall from grace, his more concrete or literal deployment of the figure seems to limit women's role in revelation to the first stages of transformation: subordination and self-annihilation.

As "Common opinion" in the eighteenth century shifted from a focus on three bodies to a focus on two bodies ("male and female created he them"), Blake invoked the already outdated concept of the hermaphrodite to shift from two bodies (male and female) to one body alone. In his work, the hermaphrodite comes to be a figure for sexual division-for the mistaken belief in differentiated male and female bodies when (outside the limits of Generation) the poet will admit the existence of only one " $\mathrm{Hu}-$ man" body. Yet that one body remains male. Blake's denial of two biological sexes can be read as both profoundly radical and profoundly

three classes of men through Milton's taking off the robe of the promise on to the appearance of Jesus in the apocalyptic 'Garment dipped in blood' that emerges from the dispelled clouds of Ololon on the forty-second plate" (Blake's Apocalpse 396), and James Rieger adds to this list "the cruelty in which the Shadowy Female clothes the image of God, Jerusalem's long sufferings as the garment of God, and the vegetable world that Blake binds on as a bright sandal to walk forward through eternity" (James Rieger, “'The Hem of their Garments': The Bard's Song in Milton" in Blake's Sublime Allegory 278). Elsewhere in his essay, Rieger also draws attention to the garments of creation: the "gorgeous clothed Flies" and the prophetic trees which are "the Sons of Los! These the Visions of Eternity / But we see only as it were the hem of their garments" (26:IO-II). In many cases, garments associated with male figures are seen in a positive light, while those associated with women are viewed as abomination. 
conservative, as more recent debates around the claim "Woman does not exist" may demonstrate. On the one hand, a single Human body solves the kinds of problems Mary Wollstonecraft encountered in her attempt to claim for women "male" virtues and education. If Humanity lies beyond sexual division, all members of that single humanity have an equal claim to virtue and education. On the other hand, Blake rather notably does not succeed in writing beyond the sexes: the female remains within the structure of his prophecies as a degraded or an invisible term.

As Milton's "terrible majesty" in addressing Ololon-as-virgin may suggest, this prophetic structure reinscribes and supports patriarchal, even monarchical, systems of power. Yet Blake's more explicit political project remains the radically democratic attempt to create prophets. Within the world of the prophecy, the category of sex remains both a constraint (when sex is understood as biological fixity) and as a source of power and energy (when sex is understood as erotic desire). "The Sexual is Threefold: the Human is Fourfold"-but Milton repeatedly demonstrates the difficulty (one might say impossibility) of thinking beyond the boundaries of the sexual.

The Preface to Milton calls upon contemporary artists to transcend the constraints of social support and critique - and to move beyond Greek and Roman models for painting and literature. As a whole, the prophecy works to purge the Christian epic Paradise Lost of an over-reliance on the warlike conventions of the classical epic. Yet Paradise Lost itself brought the conventions of warlike selfhood home to seventeenth-century England. This Christian epic links war in heaven to strife on earth as it denounces the inversion of traditional sexual politics: strife appears as daughters seduce fathers (Sin and Satan) and wives persuade their husbands to sin (Eve and Adam). Blake's Milton seems to accept the premise that relations between men and women ideally require the willing subordination of women. It complicates this premise by trying to present men and women as two halves of a single (married) identity - but as Blackstone would remind us, that single identity remains that of the man. The only role remaining for women seems to be that of the garment. I want to argue that Blake's association of female identity with garment imagery is another ambivalent bequest from the Greek and Roman models he was attempting to revise or supersede: it appears perhaps most clearly in the painter James Barry's contemporary epic, The Birth of Pandora (Figure 3).

Since there is no direct evidence that Blake was influenced by Barry's Birth of Pandora, I will try to limit myself to pointing out what seem to me a remarkable set of parallels. Both artists clearly knew of and respected each 


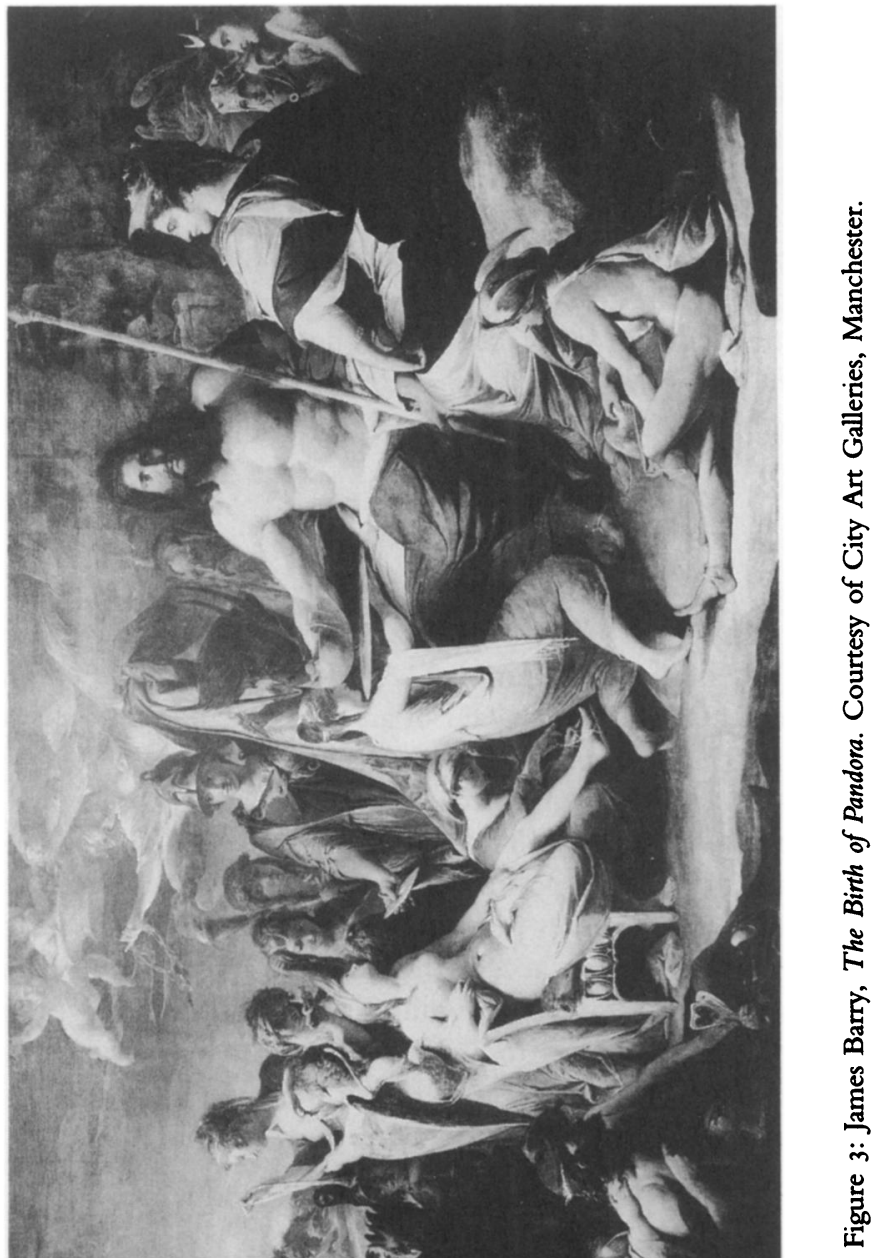

This content downloaded from 130.58.88.100 on Thu, 09 Jan 2020 14:19:51 UTC All use subject to https://about.jstor.org/terms 
other's work ${ }^{16}$ and both demonstrated a visual and conceptual fascination with Paradise Lost. During the 1790's, Barry engaged in two large-scale projects: one vast canvas depicting the Olympian gods at the birth of Pandora and a series of illustrations from Paradise Lost. As a result of various career problems (including his expulsion from the Royal Academy), Barry never completed the Paradise Lost series. Still, extant paintings show intersections between Barry's work and Blake's painting: "Fire" from Tiriel may have influenced or been influenced by Barry's "Satan calling the Legions," 17 and the frontispiece to Milton (Figure 4) is loosely reminiscent of Barry's Satan, Sin and Death (Figure 5). In this latter example, Blake replaces the armed struggle between Satan and Death with Milton's raised arm, which seems to call a halt to that earlier struggle, even as it marks the splitting of the self, the name "MIL/TON." 18

Between 1790 and $\mathrm{I} 809$, Barry produced three markedly varied descriptions of his Pandora project. John Barrell suggests that in each account,

whatever else the proposed picture is required to do, it has one task which never changes: to define and to preserve the difference between male and female, as if for Barry that difference is felt to be confused and blurred. ... Barry's seemingly endless involvement with the

I6. Barry, for instance, appears repeatedly in Blake's annotations to The Works of Sir Joshua Reynolds (I798) in contexts that suggest Blake identified with the older artist:

Having spent the Vigour of my Youth \& Genius under the Opression of Sr Joshua \& his Gang of Cunning Hired Knaves Without Employment \& as much as could possibly be Without Bread, The Reader must Expect to Read in all my Remarks on these Books Nothing but Indignation \& Resentment While Sr Joshua was rolling in Riches Barry was Poor \& [Independent] <Unemployed except by his own Energy> (636)

Who will Dare to Say that [Fine] <Polite> Art is Encouraged, or Either Wished or Tolerated in a Nation where The Society for the Encouragement of Art. Sufferd Barry to Give them, his Labour for Nothing A Society Composed of the Flower of the English Nobility \& Gentry-[A Society] Suffering an Artist to Starve while he Supported Really what They under pretence of Encouraging were Endeavouring to Depress.-Barry told me that while he did that Work-he Lived on Bread \& Apples. (636)

These notes echo (or resound in) the warning of Milton's Preface: "Suffer not the fash[i]onable Fools to depress your powers by the prices they pretend to give for contemptible works or the expensive advertizing boasts that they make of such works; believe Christ $\&$ his Apostles that there is a Class of Men whose whole delight is in Destroying." Though he is no longer a young man, Barry may be one of the Painters called on quite directly by the Preface: a consideration of Barry's work may help illuminate some of the difficulties in Blake's.

17. See William Pressly, The Life and Art of James Barry (New Haven: Yale UP, I981).

I 8. In relation to this splitting, see Thomas Vogler, "Re:Naming MIL/TON" in Unnam'd Forms: Blake and Textuality, eds. Nelson Hilton and Thomas Vogler (Berkeley: $U$ of California P, 1986). 


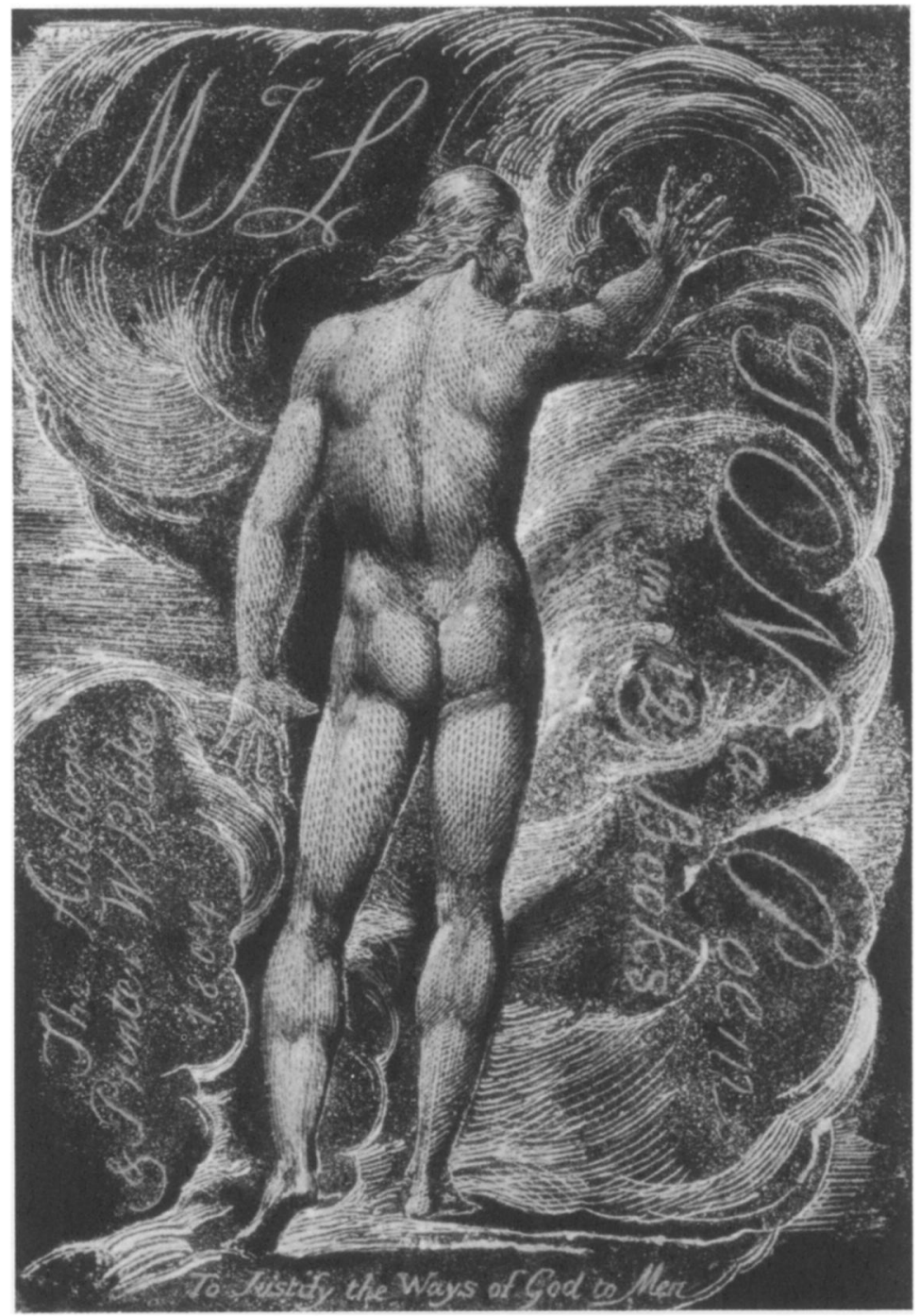

Figure 4: Milton, Plate I. Courtesy of the Huntington Library.

This content downloaded from 130.58.88.100 on Thu, 09 Jan 2020 14:19:51 UTC All use subject to https://about.jstor.org/terms 


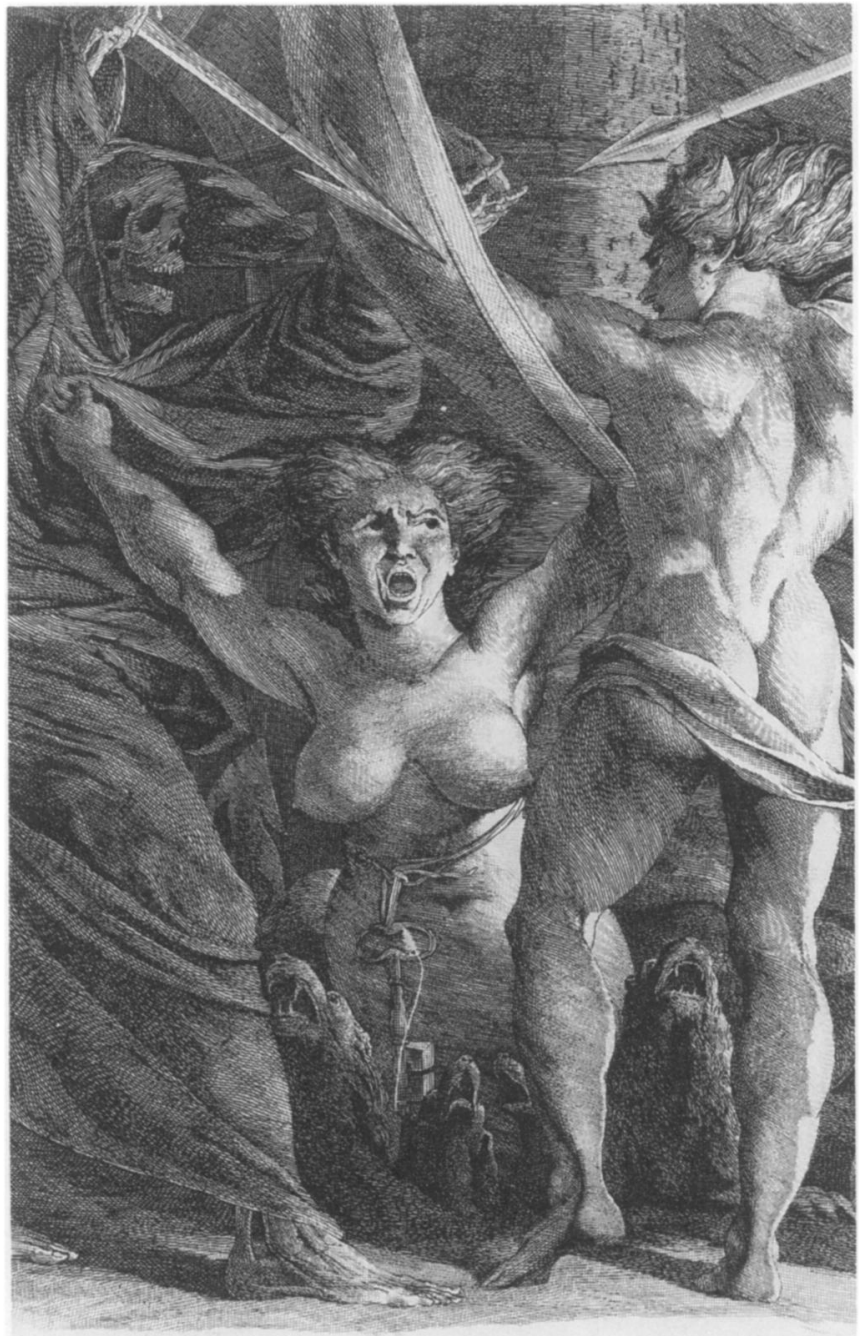

Figure 5: James Barry, Satan, Sin and Death. Courtesy of the British Museum. 
Pandora project reveals how the question of sexual differentiation is inseparable from that other, no less intractable question, of the origins and the political function of art. ${ }^{19}$

Barry's first extended description of the piece presents Pandora as the joint creation of the Olympians: the product which unifies a community visibly differentiated by gender and occupation. The female (and highly sexualized) figure of Pandora becomes a visual key for social unity. This first framing of the Pandora project is likely to have held little appeal for Blake: one suspects that a society unified by - and thus in part subordinated to-a figure of female sexuality and passivity would have seemed to him more of a perversion than an ideal.

In his second description of the painting, his 1798 Letter to the Dilettanti Society, Barry presents Minerva, goddess of painting (in tapestry), as the figure linking the Birth to Pandora to the origins of painting. ${ }^{20}$ Minerva, the most masculine (and hermaphroditic) of Olympian goddesses, at first appears to sustain the "Master art" of painting in its public, cognitive function: the kind of painting she is said to represent advances well beyond the lower art of "merely copying . . . actual, casual, ordinary nature" to produce a "new moulding and imitation" of nature. The Greeks "reserved this Master Art, this Art par excellence, to employ the . . . exertions and skill of the mistress of all, of Minerva, or Wisdom itself" (2: 586). Yet as Barry focuses on the scene of Minerva teaching Pandora to paint (in tapestry), the lessons of "this Art par excellence" are rapidly subordinated to the lessons of femininity:

an art which was capable of being made subservient to all the social duties, and where it was impossible to excel in it, without the acquisition of such information, respecting all the concerns and dearest interests of humanity, as could not fail, when joined with the superior sentiment and graces of feminine softness, to become the solace and anodyne against the numberless and unavoidable miseries of life: and as wives, mothers, daughters, sisters, citizens, and above all, as friends, these endearing accomplishments . . could not fail of rendering them the graceful ornaments of all stations. (2: 595)

19. John Barrell, "The Birth of Pandora and the Origin of Painting" in The Birth of Pandora and the Division of Knowledge (Philadelphia: U of Pennsylvania P, 1992) 149-50. Barrell's essay offers a useful guide through Barry's various descriptions of his Pandora project.

20. According to Barry, " $[t]$ he employment for which Minerva is peculiarly distinguished from all the celestial personages, is her skill in the labours of the loom. ... [S] he was sovereignly skilful in the art of painting in tapestry. . . By the skilful labours of the loom the ancients always understood the art of making pictures in tapestry" (James Barry, The Works of James Barry, ed. Edward Fryer [London: Cadell and Davies, I 809] 2: 585). 
Barry's "Master art" of public representations and cognition begins to seem indistinguishable from the arts of the mistress of the house-an affair for the Dilettanti Society after all. The tension at work in this description of the painting is also visually encoded at its center, as Pandora's upswept hair recalls Barry's earlier Venus (Figure 6). Thus while the goddess of Love appears in propria persona on the left of the painting, she is also visually present in the reclining figure Minerva attempts to instruct. Painting becomes a hermaphroditic art, mingling elements of masculine skill and wisdom with those of feminine consolation.

Barry's Birth of Pandora places two female figures at the center of society: the goddess of wisdom, visibly associated with a figure of female sexuality through a garment which records one Greek myth of "war in heaven." The garment Minerva displays to Pandora is described in 1798 as "a tapestry robe ... in which is represented . . . the story of Jove fulminating the Titans, or the punishment of that pride and arrogance which was likely soon to become apparent in the descendants of poor Pandora" (2: 595). As Minerva exhorts Pandora "to the performance of . . . respectable matrimonial duties," she also holds up before her student a picture of what happens to those who rebel. In Barry's "Fragment on Pandora" (written c. I 805 , published posthumously I 809 ), the fabric becomes a more ceremonial covering:

While Pandora is thus dressing by the Graces, her head is attentively turned towards Minerva, who with one hand is shewing her a shuttle, and earnestly exhorting her to the performance of those respectable matrimonial duties, the essence of which depends on the acquisition of that intimate knowledge of manners and things, which will enable her to design and fabricate such tapestry (truly feminine work) as the famous Peplon, or covering, which Minerva is holding up in the other hand. (2: I 53)

The "famous Peplon" was, according to Barry and his sources, "the principle ornament" of the Panathenea, which was in turn a festival celebrating the political unity of Athens. The Peplus was embroidered by the virgins of the city; on it was represented "the battle of the gods and giants. Amongst the gods was Jupiter hurling his thunder-bolts against that rebellious crew, and Minerva seated in her chariot, appearing the vanquisher of Typhon, or Encalladus" (2: I58). Thus the design of the robe held by Minerva remains roughly constant between 1798 and 1809 , though in Barry's later description, local politics mingled with divine mythology: "The names of those Athenians who had been eminent for military virtue, were also embroidered on it; Potter says, had their effigies on it, whence men of true courage and bravery were said to be Axiou tou peplou, i.e., worthy of the Peplus" (2: I58). Barry's final account of the scene of 


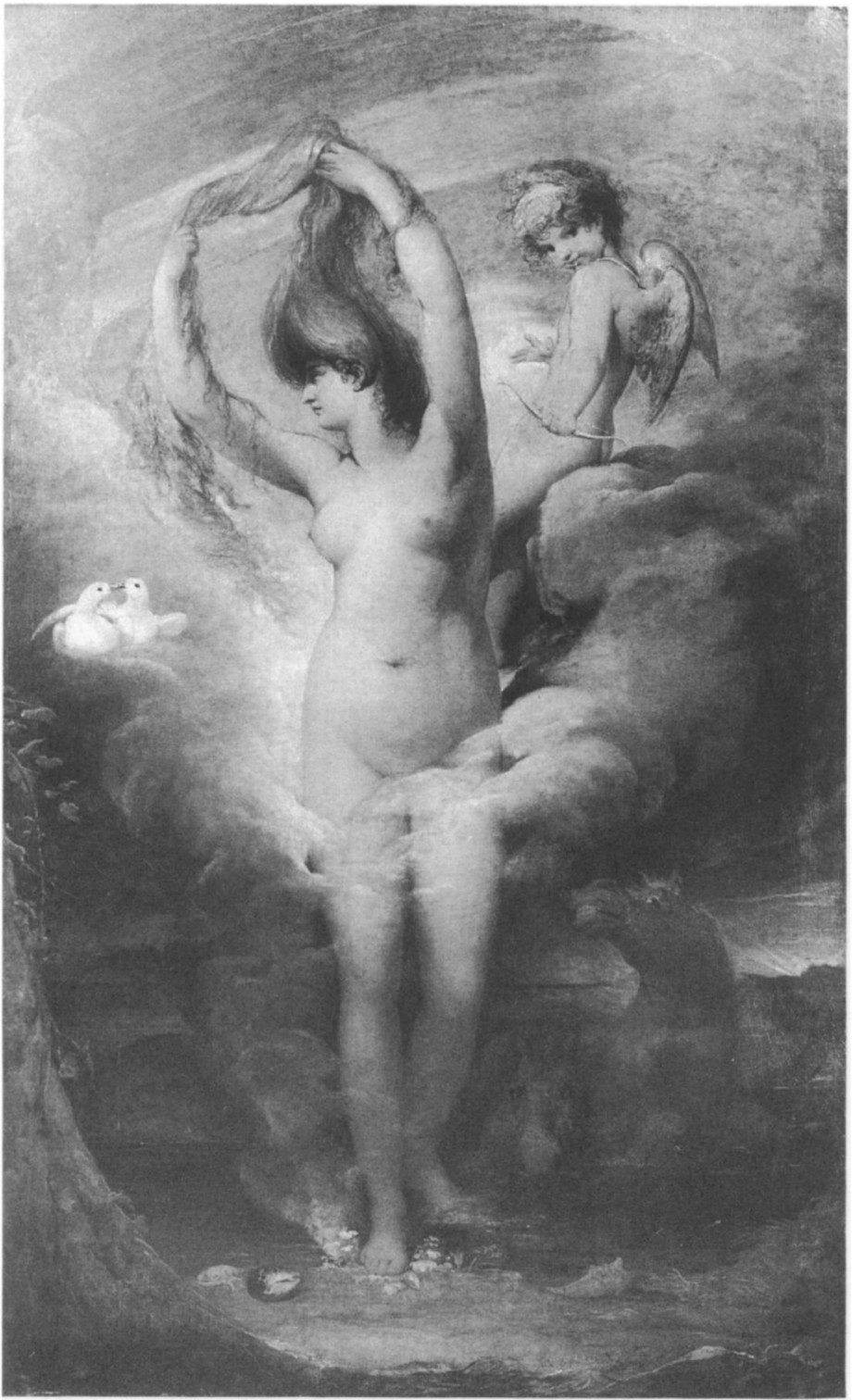

Figure 6: James Barry, Venus. Courtesy of the Hugh Lane Municipal Gallery of Modern Art, Dublin.

This content downloaded from 130.58.88.100 on Thu, 09 Jan 2020 14:19:51 UTC All use subject to https://about.jstor.org/terms 
Pandora's instruction thus attempts to reconcile strikingly different approaches to art $\rightarrow$ so that the public celebration of military virtue can be paradoxically described as "truly feminine work." Yet as John Barrell notes, "the solution thus proposed to the problem of gender can equally be read as a new version of the problem itself. What had been a function of the body in history painting has simply been displaced onto an item of clothing, and an item of female clothing at that" (I86).

Blake's Milton reenacts Barry's gesture of displacement as a structural conflation or condensation of divergent terms. Garments in Milton appear not as a solution to the problem of gender, but as a peculiarly female embodiment of suffering. Indeed, Barry's description of the Peplus as woven by virgins and celebrating Athenian military valor through embroidered effigies of military heroes seems almost a perfect prototype for the garments of the Shadowy Female:

My Garments shall be woven of sighs \& heart broken lamentations.

The misery of unhappy Families shall be drawn out into its border

Wrought with the needle with dire sufferings, poverty, pain and woe

Along the rocky Island \& thence throughout the whole Earth

There shall be the sick Father \& his starving Family: there

The Prisoner in the stone Dungeon \& the Slave at the Mill

I will have writings written all over it in Human Words

That every Infant that is born upon the Earth shall read

And get by rote as a hard task of a life of sixty years.

I will have Kings inwoven upon it \& Councellors \& Mighty Men.

The Famine shall clasp it together with buckles \& Clasps

And the Pestilence shall be its fringe $\&$ the War its girdle

To divide into Rahab \& Tirzah that Milton may come to our tents

For I will put on the Human Form \& take the Image of God,

Even Pity \& Humanity, but my Clothing shall be Cruelty

And I will put on Holiness as a breastplate $\&$ as a helmet

And all my ornaments shall be of the gold of broken hearts

And the precious stones of anxiety \& care $\&$ desperation $\&$ death

And repentance for $\sin \&$ sorrow \& punishment \& fear

To defend me from thy terrors O Orc! my only beloved!

$(18: 5-25)$

In place of Minerva instructing Pandora in the "acquisition of an intimate knowledge of manners and things," the lessons of the Shadowy Female are to be learned by every human being "as a hard task of sixty years." These are the lessons of misery: "dire sufferings, poverty, pain and woe." As military heroes were embroidered on the peplon, so kings, counsellors and mighty men are inwoven on these garments-once again, Greek and 
Roman models lead to pomp of warlike selfhood. The Shadowy Female warns, "I will put on the Human Form \& take the Image of God, / Even Pity \& Humanity, but my Clothing shall be Cruelty / And I will put on Holiness as a breastplate \& as a helmet." In Barry's painting, Minerva appears dressed in a helmet and a somewhat softened breastplate; her face is stern, perhaps even cruel.

Orc's rebuke to the Shadowy Female re-presents her garments as a Satan and a Covering Cherub; he also tries to return his mate to her properly Female Form:

Orc answered. Take not the Human Form O loveliest. Take not

Terror upon thee! Behold how I am \& tremble lest thou also

Consume in my Consummation; but thou maist take a Form

Female \& lovely, that cannot consume in Mans consummation

Wherefore dost thou Create \& Weave this Satan for a Covering [?]

When thou attemptest to put on the Human Form, my wrath

Burns to the top of heaven against thee in Jealousy \& Fear.

Then I rend thee asunder, then I howl over thy clay $\&$ ashes

When wilt thou put on the Female Form as in times of old

With a Garment of Pity \& Compassion like the Garment of God

His garments are long sufferings for the Children of Men

Jerusalem is his Garment \& not thy Covering Cherub O lovely

Shadow of my delight who wanderest seeking for the prey.

In many ways, this is an artist's critique: the Shadowy Female and Barry alike have no business equating an eternal with a merely mortal form-for such an equation results in the human form becoming Satan, the Covering Cherub. Yet there exists a proper "Female Form" to which the Shadowy Female should return: Orc's speech suggests that Jerusalem, the garment of God, may offer a redeemed version of this Satanic covering. Both garments - that of the Shadowy Female and Jerusalem alike-represent suffering, but while the former actually creates suffering, the latter (Jerusalem as the Garment of God) becomes the means by which the Divine Saviour takes on himself the sufferings of humanity. At the end of the prophecy, Jerusalem appears as the figure of Ololon redeemed: the garment of God, represented in brief succession as a multitude, a virgin, a dove, an ark, clouds of blood and streams of gore and finally a garment dipped in blood:

Then as a Moony Ark Ololon descended to Felphams Vale In clouds of blood, in streams of gore, with dreadful thunderings Into the Fires of Intellect that rejoic'd in Felphams Vale 
Around the Starry Eight: with one accord the Starry Eight became One Man Jesus the Saviour. wonderful! round his limbs The Clouds of Ololon folded as a Garment dipped in blood Written within \& without in woven letters: \& the Writing Is the Divine Revelation in the Litteral expression:

A Garment of War, I heard it namd the Woof of Six Thousand Years.

This garment dipped in blood is uncannily close to the garments of the Shadowy Female: both fabrics bear writing, both are named as garments of war. The Shadowy Female adorns her garment with "writings written all over it in Human Words;" the garment which Ololon becomes is likewise "Written within \& without in woven letters"-but in the place of Human Words, this writing becomes "the Divine Revelation in the Litteral expression." Every human being, "every Infant that is born upon the Earth shall read / And get by rote as a hard task of a life of sixty years" the writing contained within the garment of the Shadowy Female; the garment which is Ololon must be learned not by rote but by heart over the course of Six Thousand Years - that space of time in which the Poet's Work is done.

Blake's insistence on the centrality of the Poet's Work, and the excentricity of female figures and garment imagery parallels Barry's final conceptual revision of The Birth of Pandora. The painter's extended "Fragment on Pandora" maintains the scene of Minerva instructing Pandora as the center of the project, but the terms of creation have been extensively reframed. In his description of the painting, Barry promotes Vulcan to the position of artist-in-chief: "Calliope (the most advanced figure of the muses, who attentively surround Apollo) has her hand on the shoulder of Vulcan, as it were (agreeably to her office) pointing him out as the ingenious, sublime artificer of that Pandora, whose education and interests occupy the attention of the whole assembly" (2: I 54). Barry likewise shifts the reader's attention away from the kind of painting Pandora is being taught, towards the kinds of creation ascribed to the limping god:

whilst the fascinating manners and mental qualities of Pandora are made to be the gift of other gods, yet the substratum or material fabrication, organization, and vitality, are obtained from the complicated energies and skill of Vulcan, whose character (instead of the mere blacksmith) is by this ingenious and most apposite fable, exalted into the more sublime symbol of the active principle, the busy element of fire, the great operator even of the other elementary energies which counteract the torpor and inertness of mere material things (2: I 54) 
As Barry emphasized Vulcan's role in the creation of Pandora, Blake makes a sculptor-blacksmith the hero of his narrative and the center of his prophecy. Milton and Los are both shapers of inanimate matter, and midway through the poem Los joins with Blake, the poem's hero-in-waiting. Like Vulcan, Los (the Spirit of Prophecy) is an "ingenious sublime artificer," albeit one who continues to labor at his forge: his Sons are sculptors and artists. Yet the real art of prophecy appears only when the descending poet Milton himself becomes a sculptor: "Silent Milton stood before / The darkened Urizen; as the sculptor silent stands before / His forming image; he walks round it patient labouring." In Hesiod's Theogony and Works and Days, Hephaistos, the limping god, is one of the gods largely responsible for crafting Pandora as a kalon kakon, a "beautiful evil." In Barry's account of the "Birth of Pandora," Vulcan provides the material "fabrication, organization and vitality" which supports the gifts of all the other gods; meanwhile Barry separates the "evil" of Pandora from her body into the contents of "that fatal vase" (2: 1 54). In Blake's Milton, by contrast, the emblematic labor of the prophetic artist is neither the creation of a beautiful evil nor the mere fabrication and organization of raw materials; rather, the prophet's arduous task is to transform the icy intellect, to humanize the demons of Abstract Horror and perceptual limitation (Urizen as the boundary of the horizon).

As we have seen, Barry's description of the Birth of Pandora tends to present the scene of instruction as the center of the painting; yet in seeking the center, the viewer's eye is also drawn to the figure of the third Grace who is in the process of tying a sandal on Pandora's extended foot. In the right foreground as well, "Mercury putting on his talaria [winged sandals] is preparing to carry down Pandora to her destined husband" (2: I 54). This doubled donning of sandals recurs, oddly rearranged, in Milton. After Milton has fallen into Blake's left foot,

all this Vegetable World appeard on my left Foot, As a bright sandal formd immortal of precious stones \& gold:

I stooped down \& bound it on to walk forward thro' Eternity

$(21: 12-14)$

Where Barry's Vulcan organizes bits and pieces of inanimate matter into a female form, Blake shows the entire Vegetable World, still unified, suddenly transformed into a humble article of prophetic apparel. (It would hardly do, in Blake's terms, for a figure of the Eternal Great Humanity Divine to be composed out of some primal soup of dismembered parts.) While Barry's Pandora is to be carried to her destined husband, Blake's sandal is designed explicitly for walking through Eternity; in these terms, the character Blake seems closer to the figure of Mercury than to that of 
Pandora. Blake does indeed appear to move forward through (or into) Eternity, for the next stanza brings the poem's first mention of Ololon, and of the lamentations that will lead to Ololon's descent. And even as Ololon begins to be shaped as a composite figure, made up of multitudes, so the character Blake is refigured in composite terms, combined with Los:

While Los heard indistinct in fear, what time I bound my sandals On; to walk forward thro' Eternity, Los descended to me: And Los behind me stood; a terrible flaming Sun: just close Behind my back; I turned round in terror, and behold. Los stood in that fierce glowing fire; \& he also stoop'd down And bound my sandals on in Udan-Adan; trembling I stood Exceedingly with fear \& terror, standing in the Vale Of Lambeth: but he kissed me and wishd me health. And I became One Man with him arising in my strength: Twas too late now to recede. Los had enterd into my soul: His terrors now posses'd me whole! I arose in fury $\&$ strength.

While the Graces, Mercury and Pandora all remained distinct, Blake and Los become a single, composite form. The energies of this passage seem (fiercely, flamingly) erotic as well as creative: the design (Figure 7) positions Blake's kneeling figure in between the legs of the sun-god; Blake's head, turned backwards to face Los, is just slightly lower than the juncture of those legs. The two men kiss; Los "enters" Blake's soul and in emotional terms "possess[es] him whole"-and Blake is strengthened by the experience of possession.

At the same time, Los stooping down to bind on Blake's sandals establishes Blake in the position of Barry's Pandora, being dressed by an immortal. (The erotic charge of Pandora's upswept hair may also have been channeled into this moment of union between the two prophets.) Joseph Wittreich points out that within the conventions of prophecy "to strap on the sandal is a sign that the prophet, no longer impoverished, has achieved an integrated personality, is about to throw 'his whole self into his prophecy', making 'not his lips alone, but his whole personality,' the vehicle for the divine word" (Wittreich 250). The reshuffling (so to speak) of sandals replaces Pandora, the created female, with the combined figure of Blake and Los, the integrated prophet and creative male artist. What cannot be integrated is the figure of Pandora. Blake and Los remain unified through an item of clothing, the sandal, which points back toward that unrecuperable supplement.

By the conclusion of the poem, not only the sandal but also the garment imagery identified with the Covering Cherub has become a figure for poet 


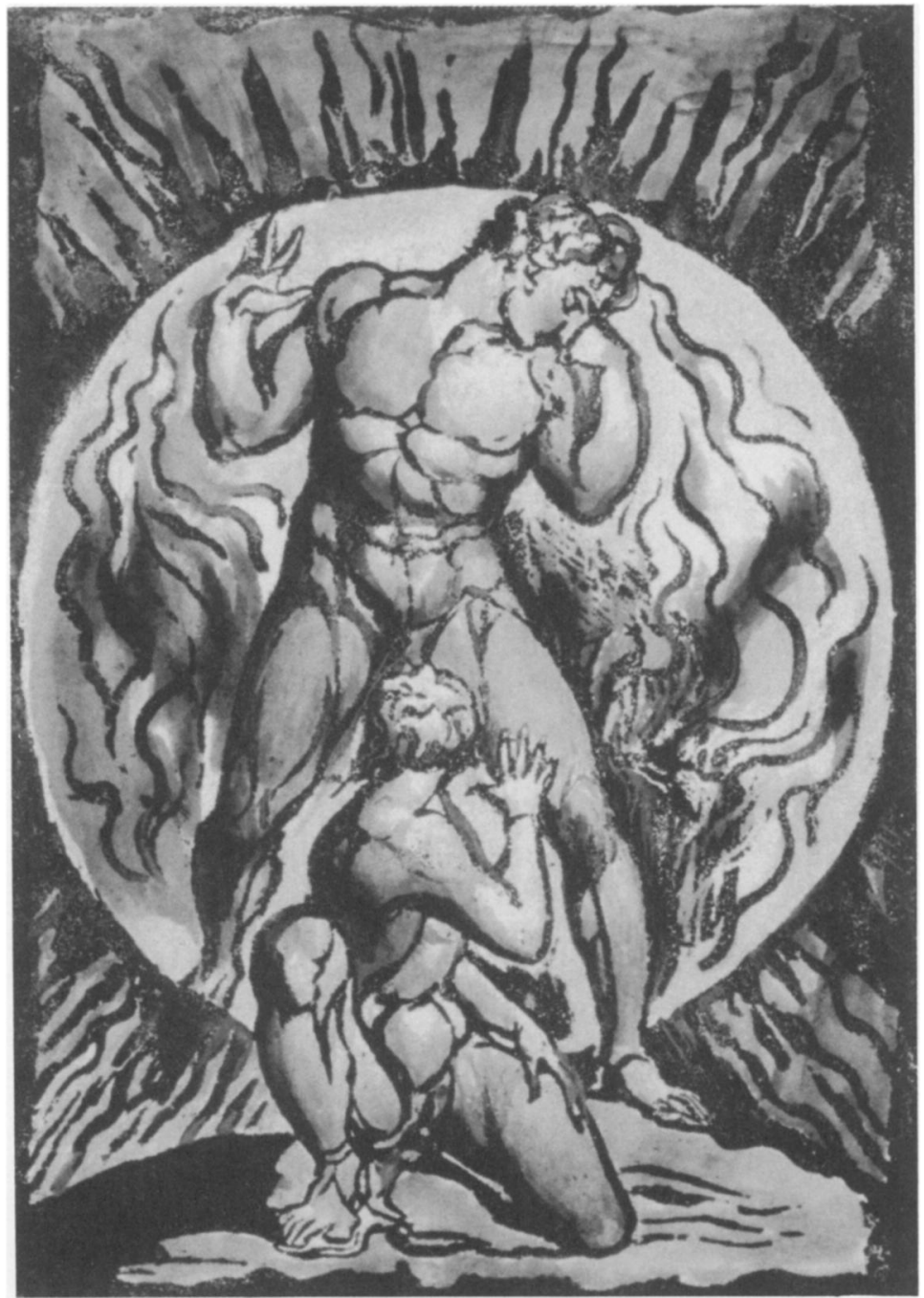

Figure 7: Milton, Plate 21. Courtesy of the Huntington Library. 
and prophecy combined. But here again it is Ololon rather than Blake who has thrown their/her/its whole self into the prophecy, and as a result, ceased to appear in human form (at least for the duration of this poem). The twelve-year-old virgin and the Eternal Host alike sacrifice themselves to the prophecy: rather than giving voice to the prophecy, they give their lives. In Barry, the peplus depicts male figures and connects two female figures. In Blake, the garment dipped in blood is still a female figure (Jerusalem) connecting two men: Jesus/Milton and Blake, the man who bears witness to this prophecy. Like the sandal on which Blake walks forward through eternity, this garment, once female and now a literal expression of the divine revelation, ties vision back to earth. Blake says of his union with Los: "I became One Man with him arising in my strength." So too the Starry Eight become "One Man Jesus the Saviour. wonderful!" In each case, however, this One Man seems to be grounded in a vanished female figure whose return to inanimate matter lends sacrificial strength to the prophet. Blake's "One Man," his rejection of sexual duality depends upon an ever-present, ever-vanishing and devalued female term. Perhaps for this reason, within the six thousand years of the Poet's Work in the realm of Generation, Ololon continues to appear as a "Garment of war."

4

The comparison of Blake's prophecy with Barry's life project indicates the extent to which the politics of art are inseparable from the politics of gender (more specifically, perhaps, the politics of masculinity) during the early romantic period. I have tried to argue for the importance of considering such gender politics within a slightly larger historical context. The eighteenth century, shifting from three sexes to two produced two (asymmetrically) stigmatized genders: the sodomite and the sapphist. Blake, in moving from two sexes to one, seems to produce two stigmatized sexeswomen and hermaphrodites - as he privileges men and creates a space for an unstigmatized homoeroticism. Yet this is perhaps too unified and coherent a reading of the poem: Satan's delusive love for Palamabron is condemned (if only for its delusion) and hermaphrodites are often described as both beautiful and cruel in a poem which emphasizes the cruelty of almost all created forms.

One might do better to note the prevalence of sexual deviance in a poem delivering a call to action in an age which equated sexual and political deviance quite directly. Blake's One Man, challenging the heterosexual base of patriarchy, can be read as a profoundly political figure-though its politics carry dangerous consequences for women. Barry gradually dethrones the female figures at the center of his epic painting; Blake unravels the female (Ololon) at the turning point of his prophetic narrative. Blake's 
construction of the One Man produces a proliferation of whores, hermaphrodites and homoeroticism in Milton-a violent irony in view of the poem's title character-but the treatment of women and hermaphrodites within the prophecy might be said to comprise Blake's own Covering Cherub as well as that of his predecessor.

Still, there is a Self within that (masculine) Hood, for Blake as for Milton-and Blake's Self becomes visible in part through the dramatic limits of his ability to see Ololon and Milton at the close of the poem. In $A$ Vision of the Last Judgment, Blake says that in relation to Chronos or Time, "I have <however> somewhat accomodated my Figure of Time to $<$ the $>$ Common opinion as I myself am also infected with it \& my Visions also infected \& I see Time Aged alas too much so $>$." In the very next paragraph, he goes on to assert, "Allegories are things that Relate to Moral Virtues Moral Virtues do not Exist they are Allegories \& dissimulations $<$ But Time \& Space are Real Beings a Male \& a Female Time is a Man Space is a Woman \& her Masculine Portion is Death>" (563). The assertion "But Time \& Space are Real Beings a Male \& a Female" sounds especially odd, following as it does this tautology of allegorical non-existence, and Blake's earlier acknowledgement of infected vision. The positioning of the gendered formula, "Time is a Man Space is a Woman \& her Masculine Portion is Death," invites us to read it also as an infection of vision, as an allegory and a dissimulation.

The formula "Time is a Man Space is a Woman" places gender and division at the heart of the poet's work, for time and space are the raw material of poetic creation. But error is also raw material for poetry. In $A$ Vision of the Last Judgment, Blake conflates error and creation:

Error is Created Truth is Eternal Error or Creation will be Burned Up \& then \& not till then Truth or Eternity will appear It is Burnt up the Moment Men cease to behold it I assert for My self that I do not behold the Outward Creation \& that to me it is hindrance \& not Action it is as the Dirt upon my feet No part of Me. (565)

The syntax here conflates error and creation: both exist only to be burnt up, unbeheld, to define what is "No part of Me." Yet if creation and error are synonymous, how is the poet to justify his own acts of creation (error)? This passage suggests that creation and prophecy are not necessarily equivalent (or even assimilable) terms: prophecy presents a call to annihilation, to the conflagration that ushers in Eternity; poetry and art create mistaken yet consoling forms. Blake becomes One Man not with Milton, annihilating himself to become the Divine Saviour, but rather with the Shadowy Prophet Los(s), whose sons devote themselves to adorning (and thus perpetuating) Satanic space. 
Still those ornaments provide a source of sustenance. The most famous and most frequently excerpted passages of Book One transform time and space alike into imagination; they do so in part by envisioning time in spatial terms and space as a figure of Eternity:

But others of the Sons of Los build Moments \& Minutes \& Hours

And Days \& Months \& Years \& Ages \& Periods; wondrous buildings

And every Moment has a Couch of gold for soft repose,

(A Moment equals a pulsation of the artery)

And between every two Moments stands a Daughter of Beulah

To feed the Sleepers on their Couches with maternal care.

And every Minute has an azure Tent with silken Veils.

And every Hour has a bright golden Gate carved with skill.

And every Day \& Night, has Walls of brass \& Gates of adamant,

Shining like precious stones $\&$ ornamented with appropriate signs:

And every Month, a silver paved Terrace builded high:

And every Year, invulnerable Barriers with high Towers.

And every Age is Moated deep with Bridges of silver \& gold.

And every Seven Ages is Incircled with a Flaming Fire.

Now Seven Ages is amounting to Two Hundred Years

Each has its Guard. each Moment Minute Hour Day Month \& Year.

All are the work of Fairy hands of the Four Elements

The Guard are Angels of Providence on duty evermore . . .

While the material splendor of this passage entices and soothes, its terraces and precious stones also recall Satan's fall into opacity: "his bosom grew / Opake against the Divine Vision: the paved terraces of / His bosom inwards shone with fires, but the stones becoming opake!" (9:30-33). More generally, the emphasis on enclosure ("Walls of brass \& Gates of adamant," "invulnerable Barriers," "Moated deep," "Incircled with a Flaming Fire") ought perhaps to raise suspicions. This passage produces a highly ornamented fortress mentality in relation to time; the close of the passage-its most famous lines-promptly renounces these elaborate enclosures:

Every time less than a pulsation of the artery

Is equal in its period \& value to Six Thousand Years.

For in this Period the Poets Work is Done: and all the Great Events of Time start forth \& are concievd in such a Period Within a Moment: a Pulsation of the Artery.

$$
\text { (28:44-29:3) }
$$

The "Pulsation of the Artery" places time quite specifically in the channels of the body even as it disrupts the elaborate and minute boundaries of 
"Moments \& Minutes \& Hours / And Days \& Months \& Years \& Ages $\&$ Periods." Blake closes the circle of eternity by inserting "such a Period / Within a Moment": the largest unit fits back within the smallest. Here the Satanic translation of time into space is redeemed by being quite literally humanized-at once embodied in the pulsation of the artery and transformed into "Poets Work," the labors of the imagination.

Yet that pulsation of the artery also marks the limits of creation: limits that include the poet's own particular blindnesses and limitations. I began this essay at the end of the prophecy, and in many ways have been reading backwards all along. Let me end with the poem's beginning:

Daughters of Beulah! Muses who inspire the Poets Song

Record the journey of immortal Milton thro' your Realms

Of terror \& mild moony lustre, in soft sexual delusions

Of varied beauty, to delight the wanderer and repose

His burning thirst $\&$ freezing hunger!

The Muses are to record Milton's journey in "soft sexual delusions of varied beauty": the record will be deluded, unevenly beautiful, and limited to what can be understood within the three-fold realm of sex. The journey can be recorded in no other way: if creation itself is error, poetic creation is soft sexual delusion. For Blake to speak four-fold, fully Human truth would be to watch his words burn up before his eyes. The prophecy as a whole is thus framed as error-but an error which produces varied beauty, capable of granting delight as it satisfies burning thirst and freezing hunger.

"Come down into my hand," Blake continues,

By your mild power; descending down the Nerves of my right arm From out the Portals of my Brain, where by your ministry The Eternal Great Humanity Divine. planted his Paradise, And in it caus'd the Spectres of the Dead to take sweet forms In likeness of himself.

$$
(2: 6-10)
$$

The Eternity of mental strife Blake describes has of course been this world of his own imagination all along-an imagination set in the land of Albion - and the spectres that appear (Milton, Urizen, Satan) are likenesses of himself. If the spectral Milton must descend to retrieve and make peace with his Feminine Portion, his likeness to Blake suggests at least some prophetic awareness of the gender trouble distorting the prophecy. The prophecy itself is admittedly sexual delusion: Blake's Muses descending from his brain to offer him consolation, repose, delight. The One Man is 
in fact, one man. In his annotations to the Bishop of Llandaff's Apology for the Bible, Blake wrote:

Prophets, in the modern sense of the word, have never existed Jonah was no prophet in the modern sense for his prophecy of Ninevah failed Every honest man is a Prophet he utters his opinion both of private and of public matters/Thus/If you go on So/the result is So/ He never says such a thing shall happen let you do what you will. a Prophet is a Seer not an Arbitrary Dictator. (617)

As a prophet in the classical sense, Blake is perhaps most remarkable for his unflinching honesty. It remains possible to wonder, nonetheless, what prophetic songs Ololon and the Daughters of Enitharmon might have sung to Catherine Blake - and what an eighteenth-century prophet, an honest woman speaking her opinion of both private and public matters, might have made of Blake's Milton.

Swarthmore College 